\title{
ШТО Е ПОВАЖНО ЗА УСПЕХОТ НА УЧЕНИЦИТЕ И СТУДЕНТИТЕ - ИНТЕЛИГЕНЦИЈАТА ИЛИ ДРУГИ ОСОБИНИ?
}

\author{
Виолета Петроска-Бешка ${ }^{1}$

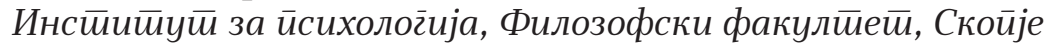

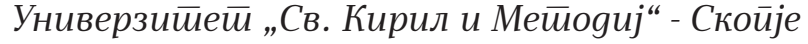

\section{Кратка содржина}

Трудот е базиран на емпириско истражување спроведено со цел да се провери колку студентите по психологија се свесни за улогата на ревноста (истрајноста/упорноста, фокусираноста и трудољубивоста), самодовербата и одговорноста во определување на образовните постигања и дали веруваат дека интелигенцијата може да се развива во текот на формалното образование. Во истражувањето беа вклучени студенти по психологија од државните универзитети во Скопје и Тетово (вкупно 314), кои одговараа на два вида прашања кои бараа: (1) рангирање на важноста на интелигенцијата и на некогнитивните особини во определување на образовните постигања на учениците и на студентите посебно и (2) определување на уделот на наследството, семејството и училиштето во развојот на секоја од проценуваните особини одделно. Резултатите покажаа дека испитаниците ги сметаат интелигенцијата и трудољубивоста како најбитни детерминанти на училишниот успех, додека пак како детерминанти на успехот на студии на исто рамниште со интелигенцијата се ставаат одговорноста и истрајноста/упорноста. Истражувањето укажа и на тоа дека најголем дел од испитаниците ја потценуваат улогата на училиштето во развивањето на некогнитивните атрибути, а на интелигенцијата гледаат како на вродена особина. Во духот на современите сфаќања во психологијата, тоа значи дека кај идните психолози доминира фиксен наместо развоен умствен склоп, што е контрапродуктивно ако се земат предвид потребите училиштето да придонесе учениците да веруваат дека вложувањето доволно напор и неоткажувањето кога ќе се наиде на проблем или се доживее неуспех придонесува за развој на интелектуалните способности и води кон повисоки постигања во образованието и во животот воопшто.

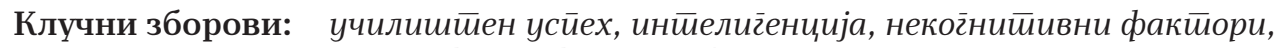

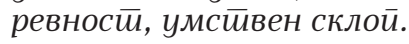

vpbeska@yahoo.com 
В. ПЕТРОСКА-БЕШКА: ШТО Е ПОВАЖНО ЗА УСПЕХОТ НА УЧЕНИЦИТЕ И СТУДЕНТИТЕ...

Во научната и стручна јавност одамна не се спори улогата што интелигенцијата ја има во предвидување на успехот од учењето, но сѐ уште засилено се истражува уделот на најразлични некогнитивни фактори во образовните постигања на учениците. Во литературата се посочуваат различни причини зошто учениците со исто ниво на интелигенција имаат различен училиштен успех, односно зошто некои ученици со пониска интелигенција имаат повисоки просечни оценки од некои ученици со повисока интелигенција. Причините се бараат во различни однесувања, вештини, ставови и стратегии кои, иако вон доменот на когнитивните способности на учениците, се вклучени во определување на нивните училишни постигања. Со други зборови, освен знаењата од материјалот што се учи во училиште и носечките когнитивни особини и вештини кои може објективно да се мерат со тестови, оценките на учениците одразуваат и некогнитивни однесувања, ставови и стратегии кои се суштински за постигнување успех не само во училиште, во подоцнежното школување (Conley, 2007), туку и на пазарот на трудот и во животот воопшто (Farkas, 2003; Heckman, Stixrud \& Urzua, 2006; Roberts, Kuncel, Shiner, Caspi \& Goldberg, 2007; Heckman, 2008; Borghans, Duckworth, Heckman, \& ter Weel, 2008; Kautz, Heckman, Diris, ter Weel \& Borghans, 2014).

Како резултат на опсежната анализа на научната литературата од областа, Фарингтон и соработниците (Farrington et al., 2012) ги групирале некогнитивните фактори поврзани со образовните постигања во пет категории: однесување, издржливост, умствен склоп (mindset), стратегии за учење и социјални вештини. Притоа, авторите на студијата го прикажуваат училишниот успех како директна последица од однесувањето кое вообичаено се поврзува со карактеристиките преку кои се опишува „добар ученик“, како што се: редовност на часовите, учење дома и пишување на домашните, внимавање и активно учество на часовите. Истовремено, другите категории некогнитивни фактори (умствениот склоп, стратегиите за учење што се користат, социјалните вештини и издржливоста), ги третираат како детерминанти на однесувањето во образовниот контекст, преку кое индиректно влијаат врз училишниот успех на учениците.

Во образовниот контекст, под издржливост се подразбира „тенденција на ученикот да ги заврши училишните задачи навреме и целосно, најдобро што може, и покрај попречувањата, тешкотиите и предизвиците“ (Farrington et al., 2012; стр. 11). Со други зборови, учениците што се одликуваат со издржливост остануваат фокусирани на целта и покрај тешкотиите, настојувајќи да ги надминат пречките и искушенијата што им се јавуваат на патот кон остварување на целта. Според тоа, една од централните одлики на издржливоста претставува ревноста (grit), која Дакворт и соработниците ја дефинираат како 
упорност и посветеност на остварување долгорочни цели (Duckworth, Peterson, Matthews, \& Kelly, 2007). Според авторите, ревноста е подобар предиктор на образовните постигања од интелигенцијата затоа што ја обезбедува енергијата што е потребна за да се остане на паток кон целта и покрај сите предизвици и неуспеси на кои се наидува. Тоа ја прави ревноста битна карактеристика на учениците со високи постигања, побитна и од интелигенцијата и од другите когнитивни способности.

Образовната истрајност заедно со умствениот склоп е вклучена во концептот на издржливост кои му овозможуваат на ученикот да гледа подалеку од краткорочните загрижи и да истрае на патот кон постигнување на подолгорочните или повисоките цели, не потклекнувајќи пред предизвиците и неуспесите на кои наидува (Dweck, Walton, \& Cohen, 2014). Според тоа, дали ученикот ќе демонстрира издржливост ќе зависи од неговиот умствен склоп кој го поттикнува или го попречува да вложува континуиран напор на патот кон остварување на целите. Од тие причини, посебна улога во определување на училишниот успех има токму умствениот склоп на учениците.

Умствениот склоп не влијае директно врз сите други категории некогнитивни фактори, па од ставот на ученикот кон училиштето и учењето и како се гледа себе си во однос на училиштето и учењето зависи и колку ќе биде сосредоточен на целите на учењето и ќе може да ги занемарува искушенијата додека учи, манифестирајќи самодисциплина, самоконтрола и соодветно однесување што го наметнува образовниот контекст (Farrington et al., 2012). Од друга страна, училишниот успех што го постигнуваат учениците го модификува нивниот умствен склоп, кој потоа, преку другите некогнитивни фактори (однесувањето и издржливоста) влијае врз училишниот успех (Farrington et al., 2012). Тоа значи дека постигнувањето повисок училиштен успех поддржува развивање позитивен умствен склоп, кој понатаму ја подобрува издржливоста и поттикнува на однесувањето кое е предуслов за повисок училиштен успех. Истовремено, негативниот умствен склоп ја потиснува издржливоста и влијае врз однесувањето на начин кој доведува до послаб училиштен успех, кој потоа го засилува негативниот умствен склоп.

Верувањата за сопствените когнитивни способности се одразуваат на односот на учениците кон учењето, па колку труд ќе вложат во училиштето зависи од тоа дали се убедени дека трудот ќе им се исплати (Elliot and Dweck, 2005). Истражувањата на Двек и соработниците кои биле спроведени со ученици од различна етничка припадност и економски статус покажале дека нивното мислење за интелигенцијата е клучно за нивниот успехот во училиште (Dweck \& Leggett, 1988). Учениците со фиксен умствен склоп се убедени дека нивото 
В. ПЕТРОСКА-БЕШКА: ШТО Е ПОВАЖНО ЗА УСПЕХОТ НА УЧЕНИЦИТЕ И СТУДЕНТИТЕ...

на интелигенција што го поседуваат е непроменливо, за разлика од оние со развоен умствен склоп, кои веруваат дека може да ги развијат своите интелектуални способности преку вложувањето напор во учењето, користење добри стратегии за учење и насоки од други (Dweck \& Leggett, 1988; Dweck, 2006, 2008; Haimovitz \& Dweck, 2017). Анализите (Dweck et al, 2014) покажале дека учениците со развоен умствен склоп добиваат подобри оценки затоа што повеќе го ценат учењето од потребата да се покажат паметни, на вложувањето труд гледаат како на доблест затоа што придонесува за развој на нивните интелектуални способности и тешкотиите на кои наидуваат ги доживуваат како поттик за зголемување на напорот или за промена на начинот на учење. Од друга страна, учениците со фиксен умствен склоп не биле подготвени за прифаќање на предизвиците и гледале негативно на вложувањето напор затоа што и неуспехот за надминување на предизвиците и вложениот напор ги сметале за показатели на ниско ниво на интелигенција.

Некогнитивните атрибути се стекнуваат во текот на животот, па има автори кои инсистираат да се нарекуваат вештини, а не личносни особини, токму поради тоа што се подложни на учење (Kautz et al, 2014). Учењето може да се случува во училиште каде, со примена на кратки образовни програми насочени кон подобрување на некогнитивните вештини на учениците може да се постигнат суштински ефекти не само врз краткорочните, туку и врз долгорочните образовни постигања на учениците (Haimovitz \& Dweck, 2017). Во литературата постојат бројни докази што ја поткрепуваат оваа теза кога се работи за промена на умствениот склоп на учениците, за поврзување на постигањата со целите, за развивање ревност и сл. (на пример, Good, Aronson \& Inzlicht, 2003; Blackwell, Trzesniewski \& Dweck, 2007; Duckworth et al, 2007; Alan, Boneva, \& Ertac, 2019).

Со оглед на тоа што од студиите по психологија се очекува да им ги пренесат на студентите современите сознанија за улогата на когнитивните и некогнитивните атрибути во успехот од учењето, целта на ова истражување е да се провери колку студентите по психологија се свесни за тоа дека интелигенцијата и различни некогнитивни атрибути што се битни за училишниот успехот на учениците можат да се развиваат во текот на формалното образование. Истовремено, истражувањето треба да одговори и на прашањето дали студентите по психологија повеќе го вреднуваат уделот на интелигенцијата отколку на некогнитивните особини и вештини во образовните постигања на училиште и на факултет. 


\section{Метод}

\section{Мерен инсиируменй}

Во истражувањето е користен прашалник со два кластери од прашања кои се однесуваат на интелигенцијата (како когнитивна особина) и на пет некогнитивни атрибути: истрајност/упорност, фокусираност, трудољубивост (сите три индикатори на ревност), самодоверба и одговорност.

Првиот кластер го сочинуваат две прашања кои бараат да се рангираат

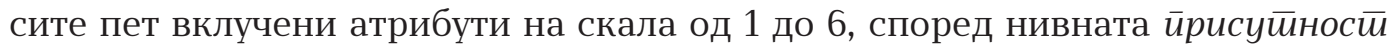
кај усиеешниие ученици во основно образование (првото прашање), односно кај

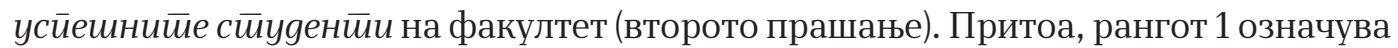
најголема присутност, а рангот 6 - најмала присутност на конкретниот атрибут. Со овие две прашања се обезбедуваат мерки на припишаната важност на интелигенцијата и на сите вклучени некогнитивни атрибути во определување на успехот на учениците, односно на студентите.

Вториот кластер прашања бараат од үчесниците да одговорат зошйо некои

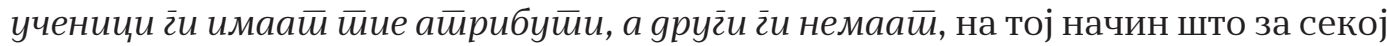
атрибут означуваат дали сметаат дека е присутен од раѓање, дали се стекнува дома и/или на училиште. Притоа, на учесниците им е дадена слобода да изберат само една, или две, или сите три понудени алтернативи. Со овие прашања се обезбедуваат мерки кои укажуваат на перцепцијата на улогата на наследството, домашната средина и училиштето во поседувањето, односно развивањето на интелигенцијата и проценуваните некогнитивни особини.

\section{Учесници и йосйайка}

Во истражувањето учествуваа студенти по психологија од Универзитетот „Св. Кирил и Методиј-УКИМ (повеќе од 70 \%) и од универзитетот во Тетово-УТ. Со оглед на тоа што истражувањето е спроведено во април и во декември 2019, во него учествуваат две генерации студенти од 3 година и една генерација студенти од 4 година, поради што доминираат помлади учесници (околу 70 \%).

Табела 1. Структура на примерокот учесници во истражувањето

\begin{tabular}{lcc}
\hline & $\begin{array}{c}\text { Прв кластер } \\
\text { прашања }\end{array}$ & $\begin{array}{c}\text { Втор кластер } \\
\text { прашања }\end{array}$ \\
\hline Универзитет „Св. Кирил и Методиј“ & 178 & 234 \\
Универзитет во Тетово & 70 & 80 \\
\hline Вкупно & $\mathbf{2 4 8}$ & $\mathbf{3 1 4}$ \\
\hline
\end{tabular}


В. ПЕТРОСКА-БЕШКА: ШТО Е ПОВАЖНО ЗА УСПЕХОТ НА УЧЕНИЦИТЕ И СТУДЕНТИТЕ..

Прашалникот (верзија на македонски или на албански јазик) им е зададен на учесниците за време на наставата. Сите присутни студенти се согласија да го пополнат прашалникот, но не сите успешно одговорија на првиот кластер прашања (не ги испочитуваа инструкциите за рангирање). Табела 1 ги отсликува двата примерока кои се разликуваа по застапеноста на студентите - едниот примерок (за вториот кластер) го сочинуваат сите студенти кои одговараа на прашалникот, а другиот (за првиот кластер) вклучува 79 \% од вкупниот број студенти и тоа само оние кои дале смислени одговори на прашањата кои бараа рангирање.

\section{Резултати}

Преку одговорите на прашањата од првиот кластер што укажуваат на припишаната важност на интелигенцијата и на некогнитивните фактори во определување на успехот на учениците, односно на студентите, добиени се мерки во вид на просечни рангови, кои се потоа обработувани со примена на соодветен непараметриски тест (Wilcoxon Signed Rank Test). Со оглед на робустните резултати што ги продуцира непараметриската статистика, добиените резултати се прикажани во сумирана верзија (табели 2 и 3). За да може да се илустрираат просечните рангови припишани на различните атрибути кои го определуваат успехот на учениците, односно успехот на студентите

Табела 2. Резултати од споредбата меѓу просечните рангови на сите атрибути кои го определуваат успехот на учениците (N=248)

\begin{tabular}{lcccc}
\hline & \multicolumn{2}{c}{ Средни рангови } & $\mathrm{Z}$ & $p$ \\
\cline { 2 - 3 } & негативни & позитивни & & \\
\hline самодоверба-интелигенција & 119,10 & 122,69 & $-4,785$ & $\mathbf{0 , 0 0 0}$ \\
истрајност/упорност-интелигенција & 105,28 & 137,85 & $-3,824$ & $\mathbf{0 , 0 0 0}$ \\
фокусираност-интелигенција & 114,19 & 127,36 & $-4,272$ & $\mathbf{0 , 0 0 0}$ \\
трудољубивост-интелигенција & 123,75 & 122,15 &,- 930 & 0,352 \\
одговорност-интелигенција & 112,21 & 128,29 & $-3,820$ & $\mathbf{0 , 0 0 0}$ \\
истрајност/упорност-самодоверба & 130,43 & 117,75 & $-1,590$ & 0,112 \\
фокусираност-самодоверба & 121,30 & 123,93 & $-1,089$ & 0,276 \\
трудољубивост-самодоверба & 131,47 & 110,02 & $-5,239$ & $\mathbf{0 , 0 0 0}$ \\
одговорност-самодоверба & 128,34 & 116,66 &,- 650 & 0,515 \\
фокусираност-истрајност/упорност & 123,22 & 123,77 &,- 255 & 0,799 \\
трудољубивост-истрајност/упорност & 124,10 & 112,43 & $-4,616$ & $\mathbf{0 , 0 0 0}$ \\
одговорност-истрајност/упорност & 119,15 & 127,71 &,- 697 & 0,486 \\
трудољубивост-фокусираност- & 127,49 & 116,08 & $-4,698$ & $\mathbf{0 , 0 0 0}$ \\
одговорност-фокусираност- & 124,39 & 123,62 &,- 235 & 0,814 \\
одговорност-трудољубивост & 108,36 & 131,06 & $-5,127$ & $\mathbf{0 , 0 0 0}$ \\
\hline
\end{tabular}


(графикони 1 и 2), користени се аритметички средини како посликовити мерки на просекот, иако статистичкиот тест за утврдување на разликите се базира на споредби меѓу медијани.

Табела 3. Резултати од споредбата меѓу просечните рангови на сите атрибути кои го определуваат успехот на студентите ( $\mathrm{N}=248)$

\begin{tabular}{lcccc}
\hline & \multicolumn{2}{c}{ Средни рангови } & $\mathrm{Z}$ & $p$ \\
\cline { 2 - 3 } & негативни & позитивни & & \\
\hline самодоверба-интелигенција & 115,18 & 126,43 & $-2,312$ & $\mathbf{0 , 0 2 1}$ \\
истрајност/упорност-интелигенција & 111,03 & 132,70 & $-1,379$ & 0,168 \\
фокусираност-интелигенција & 120,92 & 125,07 & $-3,566$ & $\mathbf{0 , 0 0 0}$ \\
трудољубивост-интелигенција & 115,41 & 125,51 & $-3,357$ & $\mathbf{0 , 0 0 1}$ \\
одговорност-интелигенција & 118,64 & 127,05 &,- 972 & 0,331 \\
истрајност/упорност-самодоверба & 135,82 & 108,32 &,- 972 & 0,331 \\
фокусираност-самодоверба & 112,88 & 134,30 & $-1,079$ & 0,281 \\
трудољубивост-самодоверба & 119,47 & 123,37 &,- 778 & 0,436 \\
одговорност-самодоверба & 122,16 & 122,91 & $-1,189$ & 0,235 \\
фокусираност-истрајност/упорност & 121,27 & 125,22 & $-2,004$ & $\mathbf{0 , 0 4 5}$ \\
трудољубивост-истрајност/упорност & 128,42 & 119,07 & $-1,671$ & 0,095 \\
одговорност-истрајност/упорност & 123,51 & 125,59 &,- 552 & 0,581 \\
трудољубивост-фокусираност- & 121,73 & 125,35 &,- 134 & 0,894 \\
одговорност-фокусираност- & 126,12 & 116,49 & $-2,492$ & $\mathbf{0 , 0 1 3}$ \\
одговорност-трудољубивост & 132,01 & 111,48 & $-2,151$ & $\mathbf{0 , 0 3 1}$ \\
\hline
\end{tabular}

За да може полесно да се следат добиените разлики меѓу просечните рангови на сите атрибути кои го определуваат успехот на учениците и на студентите одделно, добиените резултати од табела 2 и 3 се сумирани во графикон 1 и графикон 2. Графикон 1 покажува дека највисоко рангирани атрибути се интелигенцијата и трудољубивоста и меѓу нив не постои разлика во просечниот ранг. Пониско рангирани од нив се сите останати атрибути (истрајност/упорност, фокусираност, одговорност и самодоверба), меѓу чии просечни рангови не постои разлика. 


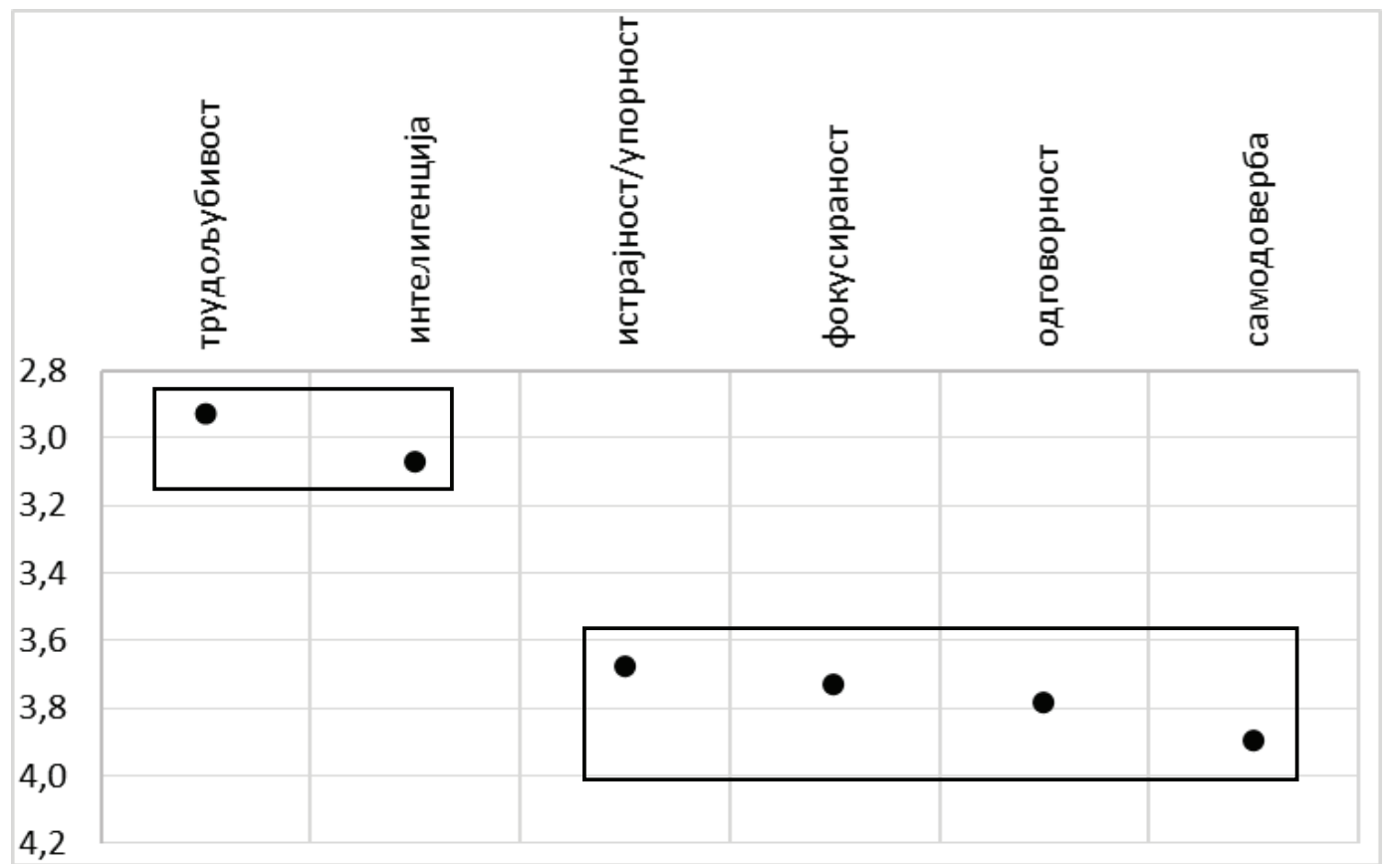

Графикон 1. Илустрација на групирањето на атрибутите кои го определуваат успехот на учениците (според просечните припишани рангови)

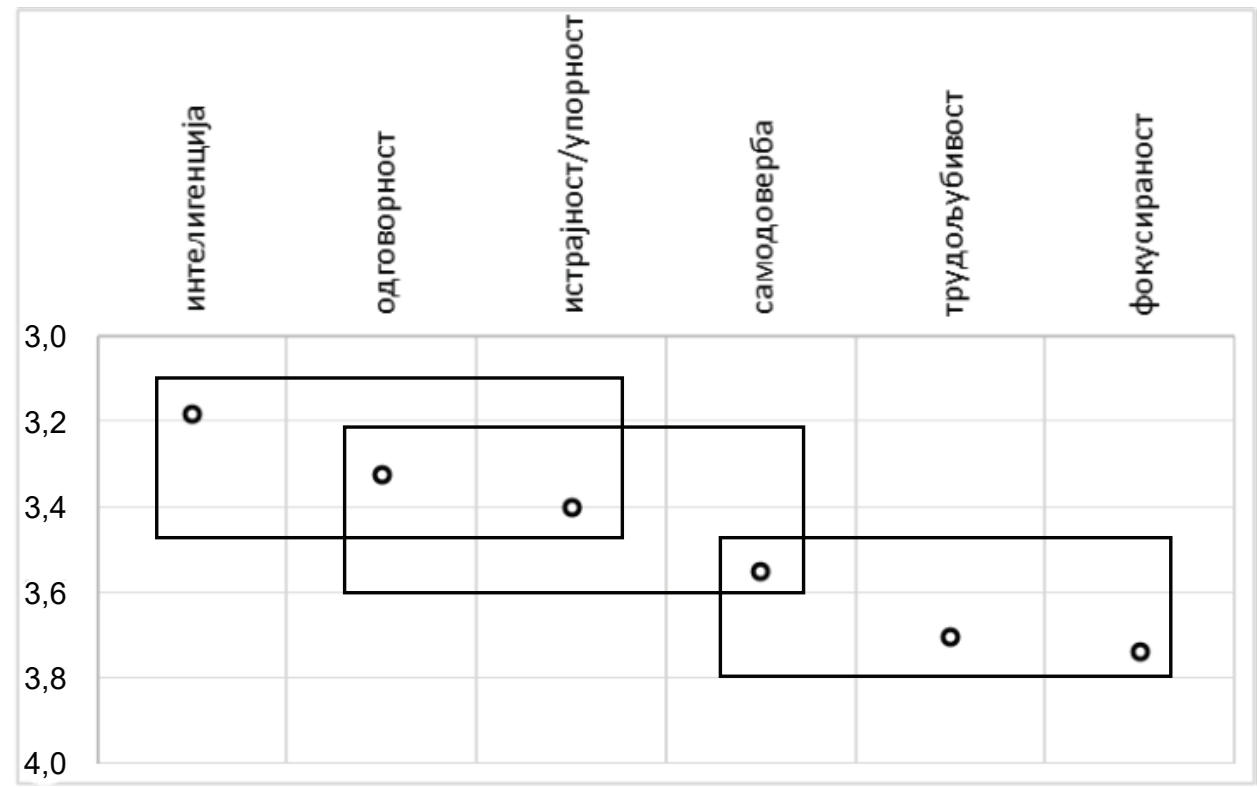

Графикон 2. Илустрација на групирањето на атрибутите кои го определуваат успехот на студентите (според просечните припишани рангови) 
Резултатите прикажани во графикон 2 (и табела 3) не оддаваат толку јасна слика за разликите меѓу просечните рангови доделени на атрибутите кои го детерминираат успехот на студиите. На прв поглед изгледа дека највисоко рангирана е интелигенцијата, а најниско фокусираноста и трудољубивоста. Меѓутоа, статистичката анализа покажува дека просечниот ранг доделен на интелигенцијата не се разликува од просечните рангови доделени на одговорноста и истрајноста/упорноста, но е значајно повисок не само од просечните рангови што се добиени за фокусираноста и трудољубивоста, туку и од просечниот ранг за самодовербата. Натамошната споредба меѓу просечните рангови укажува дека меѓу одговорноста, истрајноста/упорноста и самодовербата не постојат значајни разлики, исто како што не постојат значајни разлики меѓу просечните рангови доделени на трудољубивоста и фокусираноста.

Од споредбата меѓу просечните рангови доделени за одделните атрибути кои се однесуваат на успехот на учениците и просечните рангови доделени за истите атрибути кои се однесуваат на успехот на студентите (табела 4) произлегуваат неколку констатации. Прво, не постои разлика од едно до друго ниво на образование кога се работи за висината на ранговите припишани на интелигенцијата (подеднакво високи) и на фокусираноста (подеднакво пониски). Второ, просечните рангови припишани на самодовербата, истрајноста/ упорноста и одговорноста кога се работи за успехот на студии се повисоки од оние припишани на истите атрибути кога се работи за училишниот успех. И трето, единствена разлика во просечните рангови во корист на училишниот успех е најдена за трудољубивоста.

Табела 4. Резултати од споредбата меѓу просечните рангови припишани на одделните атрибути кои го определуваат успехот на студентите наспроти успехот на учениците $(\mathrm{N}=248)$

\begin{tabular}{lcccc}
\hline & \multicolumn{2}{c}{ Средни рангови } & $Z$ & $p$ \\
\cline { 2 - 3 } & негативни & позитивни & & \\
\hline интелигенција & 89,67 & 89,35 &,- 772 & 0,440 \\
самодоверба & 100,38 & 93,57 & $-2,296$ & $\mathbf{0 , 0 2 2}$ \\
истрајност/упорност & 109,62 & 90,01 & $-2,068$ & $\mathbf{0 , 0 3 9}$ \\
фокусираност & 101,74 & 98,38 &,- 228 & 0,820 \\
трудољубивост & 85,37 & 107,42 & $-5,249$ & $\mathbf{0 , 0 0 0}$ \\
одговорност & 107,80 & 97,13 & $-3,058$ & $\mathbf{0 , 0 0 2}$ \\
\hline
\end{tabular}

Добиените одговори на прашањето дали учениците/студентите ги имаат проценуваните атрибути од раѓње или ги стекнале дома или на училиште (или се резултат на комбинација од две/три од посочените фактори) се прикажани во графикон 3 во вид на проценти. За утврдување на значајност на разликите 
меѓ добиените проценти од еден до друг фактор во рамки на ист атрибут, односно од еден до друг атрибут во рамки на ист фактор, користен е соодветен непараметриски тест за разлики меѓу пропорции во услови на нееднакви групи.

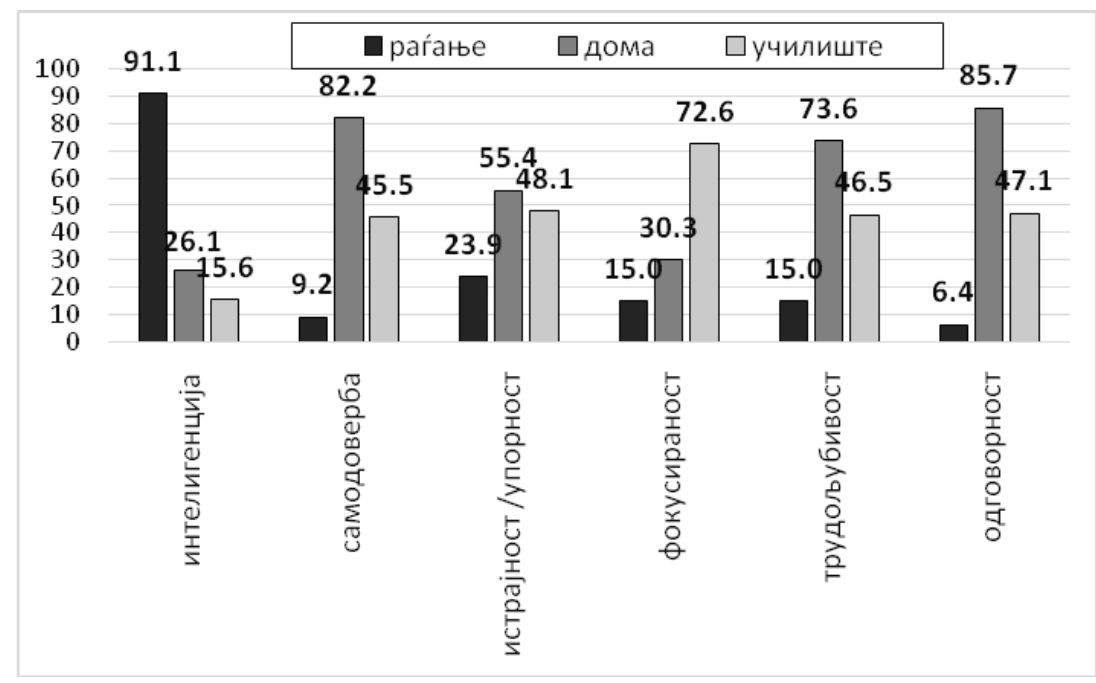

Графикон 3. Приказ на перципираниот удел на факторите наследство, семејство и училиште во поседувањето/развивањето на проценуваните атрибути кај учениците/студентите $(\mathrm{N}=314)$

Од резултатите прикажани во графикон 3 произлегува дека најголем број од учесниците во истражувањето сметаат дека интелигенција е наследна, дека семејството е најизразен фактор кога се работи за самодовербата, трудољубивоста и одговорноста, додека пак училиштето најмногу доаѓ до израз кога се работи за фокусираноста. За истрајноста/упорноста, учесниците се поделени главно околу тоа дали се стекнува дома или на училиште. Статистичката анализа на значајноста на разликите меѓу добиените проценти ги потврдува овие констатации.

Деталната анализа на податоците добиени за интелигенцијата укажува на тоа дека од вкупниот број учесници кои одговориле дека интелигенцијата ја имаме со раѓање (286), три четвртини (75,2%) мислат дека наследството е единствениот фактор, 12,6 \% мислат дека интелигенцијата се развива и дома, 4,9 \% дека се стекнува и во үчилиште, а 7,3 \% дека освен што ја имаме од раѓање, интелигенцијата се развива и дома и во училиште. 


\section{Дискусија}

Добиените резултати покажуваат дека одговорот на прашањето gали $c \bar{u} y$ -

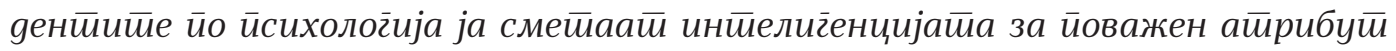

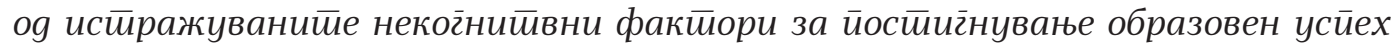
зависи од тоа дали се работи за успех на училиште или за успех на студии. Всушност, неспорно е дека на улогата на интелигенцијата во определувањето на училишниот успех/успехот на студии како когнитивен фактор иे се придава многу голема важност, но улогата на одделни некогнитивни фактори варира од едниот до другиот контекст.

За студентите по психологија постои јасна поделба на атрибутите кои го дефинираат успехот на учениците во основното училиште. Во „поважната“ група, освен интелигенцијата спаѓа и трудољубивоста, додека „помалку важната“ група ја сочинуваат истрајноста/упорноста, фокусираноста, одговорноста и самодовербата. Тоа значи дека на исто рамниште со интелигенцијата се става единствено трудољубивоста, додека на другите некогнитивни особини и вештини им се придава помало значење. Со други зборови, идните психолози сметаат дека учениците кои се поинтелигентни и подготвени да вложуваат труд се поуспешни во училиште од оние за оние за кои не важат овие атрибути. Интелигенцијата останува битен фактор за постигнување успех во студиите, но трудољубивоста, која може, но не мора да води кон успешен исход, во нивниот контекст е заменета со истрајност/упорност. Дополнително, студентите по психологија прават разлика меѓу успешниот ученик и успешниот студент и во поглед на самодовербата (како индикатор на умствениот склоп) и одговорноста (како индикатор на социјалните вештини), кои ги сметаат за поважни атрибути во контекст на високото образование. Тоа покажува дека идните психолози сметаат дека успехот на студиите е под влијание на повеќе некогнитивни фактори отколку што е тоа случајот со успехот на пониските нивоа на образование, што во голема мера се совпаѓа и со сфаќањата на авторите (на пример, Conley, 2007), според кои некогнитивните однесувања се суштински за постигнување успех во подоцнежното школување.

Еден од побитните некогнитивни фактори што се предмет на изучување во современата психолошка литература претставува ревноста (grit) за која се тврди дека е неопходна за одржување на курсот кон целта, без да се подлегне на предизвиците/ неуспесите на кои се наидува по патот (Duckworth et al, 2007). Во ова истражување ревноста е претставена преку йруgољубивосйа, без која

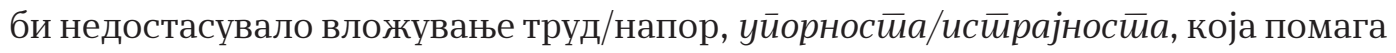
да се одолее на препреките, и фокусираноста, која обезбедува сосредоточу- 
В. ПЕТРОСКА-БЕШКА: ШТО Е ПОВАЖНО ЗА УСПЕХОТ НА УЧЕНИЦИТЕ И СТУДЕНТИТЕ...

вање на целта, односно во текот на учењето, што е предуслов за постигнување образовен успех. Резултатите од истражувањето покажуваат дека студентите по психологија не успеале да го согледаат интерактивното влијание на сите три аспекти на ревноста. Така, споредено со другите два аспекти, најмалку го ценат аспектот на фокусираност, додека пак за важноста на трудољубивоста сметаат дека доаѓ до израз само во училиштен контекст, а за упорноста/ истрајноста дека се манифестира многу повеќе на високообразовното ниво.

Истражувањето укажа на тоа дека студентите по психологија ја потценуваат улогата на училиштето во развивањето на некогнитивните атрибути. Најголем дел од идните психолози го доживуваат училиштето како најбитен медиум само кога се работи за фокусираноста (најверојатно сфатена главно како сосредоточеност на вниманието). Во врска со истрајноста/упорноста, мислењето е поделено меѓу оние кои му припишуваат најбитна улога на училиштето и оние кои сметаат дека семејството е најзначајно. Затоа пак, за тоа колкаво ќе биде нивото на самодоверба, трудољубивост и одговорност кај учениците/студентите, највлијателно се смета семејството. Со други зборови, идните психолози го доживуваат образовниот успех главно како продукт на интелигенцијата за чиј развој училиштето е немоќно. Исто така, според идните психолози, училиштето не ги развива оние особини/вештини кај учениците кои водат кон повисоки образовни успеси.

Битно е да се нагласи дека истражувањето не води кон заклучок дека студентите по психологија ги сметаат некогнитивните атрибути кои не се на рамништето на интелигенцијата за неважни, туку само дека ги проценуваат како помалку важни. Исто така, со резултатите од истражувањето се добива слика за тоа како идните психолози ја доживуваат постоечката ситуација, односно како ја проценуваат улогата на истражуваните некогнитивни фактори во постигнувањето повисок училиштен успех или успех на студии, без да го одразуваат нивниот став за тоа кои атрибути треба повисоко да се вреднуваат кога се формира оценката на учениците/студентите како објективен показател на нивниот образовен успех. Сличен коментар може да се даде и за нивната перцепција на улогата на училиштето во развојот на клучните некогнитивни фактори и на интелигенцијата - добиените резултати ја претставуваат нивната проценка на актуелната состојба, но не го одразуваат нивното мислење колку училиштето треба да биде фактор за развој на проценуваните особини.

Сепак, верувањето во непроменливоста на интелигенцијата покажува дека кај студентите по психологија-идни психолози преовладува фиксен умствен склоп. Тоа предизвикува да ја преценуваат улогата на интелектуалните способности во образовните постигања и да ја потценуваат улогата на вложениот напор за кој се смета дека придонесува не само за постигнување на целите, туку и за развивање на интелигенцијата (Dweck, 2006; Dweck \& Leggett, 1988; 
Haimovitz \& Dweck, 2017). Од една страна, фиксниот умствен склоп влијае на нивниот однос кон сопственото учење и на уверувањето дека исходите од учењето им се детерминирани од сопствените интелектуални капацитети. Од друга страна, фиксниот умствен склоп ги определува и нивните очекувања во врска со образовните постигања и на другите околу нив.

За психолозите, особено за оние кои работат со ученици во основните и средните училиштата, многу е важно да имаат развоен умствен склоп, односно да веруваат дека подобриот успех следува како резултат на тоа - што учениците повеќе го ценат учењето од потребата да се покажат паметни, а на вложувањето труд гледаат како на предуслов за развој на интелектуалните способности. Ваквиот став на психолозите може во голема мерка да придонесе за градењето училишна култура која високо го вреднува интелектуалниот развој и ги поттикнува учениците и другите чинители во образовниот процес да веруваат дека интелигенцијата може да се култивира. Дополнително, доколку училишната средина ги поттикнува учениците да вложуваат доволно напор и да не се откажуваат кога ќе наидат на проблеми или ќе доживеат неуспех, а наставниците да користат соодветни стратегии за учење, секој ученик ќе може да постигне многу и да се чувствува комотно (Ricci, 2013).

За училишните психолози е многу важно да веруваат дека ревноста со сите свои аспекти е атрибут или вештина која учениците треба да ја стекнат во училиште со цел да ја практикуваат во училишниот и во поширокиот секојдневен контекст за да ги подобруваат како своите постигања, така и сопствените интелектуални капацитети. Современите услови на живеење бараат од училиштето да ги подготви учениците да функционираат во реалноста на тој начин што ќе ги научи како да се справат со фрустрациите, како да учат од неуспесите и како да ги надминуваат пречките. Со оглед на тоа што фрустрациите и проблемите се сѐ поприсутни во реалноста, а родителите сѐ позаштитнички се однесуваат кога се работи за нивните деца, станува неопходно училиштето да ја преземе улогата на медиум кој ќе овозможи децата да ја развијат својата ревност за да станат поуспешни како во училиште, така и во животот воопшто (Hoerr, 2013).

Според Двек (Dweck, 2006), клучот на воспитувањето на децата се крие во промена на начинот на кој децата се пофалуваат и дома и на училиште. Таа смета дека на децата не треба да им се зборува за тоа колку се паметни кога ќе направат нешто успешно, затоа што тоа на подолги патеки им ја руши самодовербата: доколку успехот значи да си паметен/на, тогаш неуспехот значи да си глупав/ва. Наместо тоа, таа препорачува самодовербата кај децата да се гради така што постојано ќе им се укажува дека треба да сакаат предизвици, да учат од направените грешки, да уживаат во трудот што ќе го вложат и да бидат подготвени континуирано да учат. 
В. ПЕТРОСКА-БЕШКА: ШТО Е ПОВАЖНО ЗА УСПЕХОТ НА УЧЕНИЦИТЕ И СТУДЕНТИТЕ...

\section{Литература}

Alan, C., Boneva, T. \& Ertac, C. (2019). Ever Failed, Try Again, Succeed Better: Results from a Randomized Educational Intervention on Grit. The Quarterly Journal of Economics, 134(3), 1121-1162. https://doi.org/10.1093/ qje/qjz006.

Almlund, M., Duckworth, A.L., Heckman, J.J. \& Kautz. T. (2011). Personality Psychology and Economics. In E. Hanushek, S. Machin \& L. Woessmann (Eds.) Handbook of the Economics of Education, Vol.4, 1-181.

Blackwell, L. S., Trzesniewski, K. H. \& Dweck, C. S. (2007). Implicit theories of intelligence predict achievement across an adolescent transition: A longitudinal study and an intervention. Child Development 78(1), 246-263. https://doi.org/10.1111/j.1467-8624.2007.00995.x

Borghans, L., Duckworth, A.L. Heckman, J.J. \& ter Weel, B. (2008). The Economics and Psychology of Personality Traits. Journal of Human Resources, 43: 972-1059.

Conley, D. (2007) Toward a more comprehensive conception of college readiness. Educational Policy Improvement Center.

Dohmen, T., Huffman, D., Schupp, J., Falk, A., Sunde, U., \& Wagner, G. (2011). Individual Risk Attitudes: Measurement, Determinants and Behavioral Consequences. Journal of the European Economic Association, 9(3): 522-550.

Duckworth, A.L., Peterson, C., Matthews, M.D., \& Kelly, D.R. (2007). Grit: Perseverance and passion for long-term goals. Journal of Personality and Social Psychology, 92(6), 1087-1101. doi:10.1037/0022-3514.92.6.1087

Dweck, C. S. (2006). Mindset: The new psychology of success. Random House.

Dweck, C. S. (2008). Can personality be changed? The role of beliefs in personality and change. Current directions in psychological science, 17 (6), 391-394.

Dweck, C. S., \& Leggett, E. L. (1988). A social-cognitive approach to motivation and personality. Psychological Review, 95, 256-273.

Dweck, C.S., Walton, G.M., \& Cohen, G.L. (2014). Academic tenacity: Mindsets and skills that promote long-term learning. Bill \& Melinda Gates Foundation.

Elliot A. \& Dweck, C.S. (2005). Handbook of Competence and Motivation. Guilford.

Farkas, G. (2003). Cognitive skills and noncognitive traits and behaviors in stratification processes. Annual Review of Sociology, 29(1), 541-562. https:// doi:10.1146/annurev.soc.29.010202.100023 
Farrington, C.A., Roderick, M., Allensworth, E., Nagaoka, J., Keyes, T.S., Johnson, D.W., \& Beechum, N.O. (2012).Teaching adolescents to become learners. The role of noncognitive factors in shaping school performance: A critical literature review. University of Chicago Consortium on Chicago School Research.

Good, C., Aronson, J. \& Inzlicht, M. (2003). Improving adolescents' standardized test performance: An intervention to reduce the effects of stereotype threat. Journal of Applied Developmental Psychology, 24, 645-662. https:// doi.org/10.1016/j.appdev.2003.09.002

Haimovitz, K \& Dweck, C.S. (2017). The Origins of Children's Growth and Fixed Mindsets: New Research and a New Proposal. Child Development, 88(6), 1849-1859. https://doi.org/10.1111/cdev.12955

Heckman, J.J. (2008). Schools, skills, and synapses. Economic Inquiry, 46(3), 289-324.

Heckman, J.J., Stixrud, J. and Urzua, S. (2006). The Effects of Cognitive and Noncognitive Abilities on Labor Market Outcomes and Social Behaviour. Journal of Labor Economics, 24(3), 411-482.

Hoerr, T. R. (2013). Fostering Grit: How do I prepare my students for the real world? ASCD

Kautz, T., Heckman, J.J. Diris, R. ter Weel, B. \& Borghans, L. (2014). Fostering and Measuring Skills: Improving Cognitive and Non-cognitive Skills to Promote Lifetime Success. OECD Education Working Papers No. 110. OECD Publishing. https://doi.org/10.1787/5jxsr7vr78f7-en

Ricci, M.C. (2013). Mindsets in the Classroom: Building a Culture of Success and Student Achievement in Schools. Prufrock Press Inc.

Roberts, B.W., Kuncel, N.R., Shiner, R.L., Caspi, A. \& Goldberg, L.R.. (2007). The Power of Personality: The Comparative Validity of Personality Traits, Socioeconomic Status, and Cognitive Ability for Predicting Important Life Outcomes. Perspectives in Psychological Science, 2(4), 313-345. doi:10.1111/ j.1745-6916.2007.00047.x

Sutter, M., Kocher, M. G., Glätzle-Rützler, D. \& Trautman, S. T. (2013). Impatience and Uncertainty: Experimental Decisions Predict Adolescents' Field Behavior. American Economic Review, 103, 510-531. DOI: 10.1257/ aer.103.1.510 


\title{
WHAT IS MORE IMPORTANT FOR THE SUCCESS OF STUDENTS - INTELLIGENCE OR OTHER ATTRIBUTES?
}

\author{
Violeta Petroska Beshka
}

\begin{abstract}
The paper is based on empirical research aimed at checking whether psychology students are familiar with the role of grit (perseverance, focus and diligence), self-confidence and responsibility in determining educational achievement and whether they believe that intelligence can be improved under the influence of formal education. The research included psychology students from the state universities in Skopje and Tetovo (314 in total), who answered two types of questions that asked them: (1) to rank the importance of intelligence and non-cognitive attributes in determining the educational achievement of primary/secondary students and university students and (2) to determine the role of inheritance and social environment, especially the school, in the development of each of the assessed attributes. The results showed that the respondents considered intelligence and diligence as the most important determinants of school success, while in addition to intelligence, responsibility and perseverance were considered as determinants of academic success at university level. The research also indicated that most of the respondents underestimate the role of the school in the development of non-cognitive attributes and perceive intelligence as an innate trait. In terms of currents trends in psychology, this means that future psychologists are dominated by a fixed rather than a growth mindset, which is counterproductive given the current necessity for schools to develop students' believe that putting enough effort to exceed the obstacles and learning from own failures contributes to the development of intellectual abilities and leads to higher achievements in education as well as in life.
\end{abstract}

Keywords: school achievement, intelligence, non-cognitive factors, grit, mindset 